The central importance of peer relationships for student engagement and well being in a rural secondary school

\author{
Gristy, Cath
}

http://hdl.handle.net/10026.1/5092

10.1080/02643944.2012.671343

Pastoral Care in Education

Informa UK Limited

All content in PEARL is protected by copyright law. Author manuscripts are made available in accordance with publisher policies. Please cite only the published version using the details provided on the item record or document. In the absence of an open licence (e.g. Creative Commons), permissions for further reuse of content should be sought from the publisher or author. 


\section{The central importance of peer relationships for student engagement and wellbeing in a rural secondary school.}

\section{Abstract}

This case study records the voices of a group of young people from an isolated rural community as they reflect on their experiences of secondary school. The study was driven by a desire to develop an understanding of the human connections young people make (or not) at school, to help develop understandings of how schools can be better places for their students. The data reveals that the students report their school experience almost entirely as a social activity. In the context of this study it is argued that the emotional support and 'protection' that peer relationships seem to offer young people maybe a key element in motivating them to attend school and supporting their well being. With the focus of schools directed by inspection, standards and marketisation agenda, the importance of these peer relationships to young people may not be fully recognised by school leaders. Acknowledgement of the importance of these interactions to the students and accommodation of these needs physically and pedagogically in school, may well be a key to developing positive relations between all members of the school community.

Keywords: friends, social, well being, secondary schools

\section{Introduction}


This paper reports part of a larger case study which set out to investigate the connections young people make with and within their secondary school using a case in an isolated rural location. The importance of peer relationships to young people's engagement with school is well documented; however there are few contemporary studies in rural UK contexts. Here, young people's perspectives of their experiences of secondary school is offered as a contribution to the call for research in rural contexts using 'local voices', in and outside of school (Kvalsund \& Hargreaves, 2009).

The research was driven by a desire to develop an understanding of the human connections young people make (or not) at school, to help develop understandings of how schools can be made more inclusive and better places for their students. The case study involved an isolated rural community called Morton and the young people who went to secondary school. The community had been undergoing a period of 'neighbourhood regeneration' and an outcome of this was a focus on the role of education in the well being and life chances of its young people.

This paper reflects on the importance of the social role played by a rural school in an educational policy arena focussed on urban contexts and the 'standards agenda'. It is argued that the emotional support and 'protection' that peer relationships seem to offer young people may be a key element in motivating them to attend school and supporting their well being. With the focus of schools directed by inspection and marketisation agendas, the importance of these peer relationships to young people's well being and flourishing may not be fully recognised by school leaders.

Young people of secondary school age have lives inherently predestined for increased levels of social interaction. In the case of rural communities, secondary schools are likely to be the sites of the greatest collections of young people in the region. When the inherent need for social interaction for students is not acknowledged 
or given space in school, difficulties arise. Peer relationships within the 'informal layers' of a school, the interactions among students, among staff and between students and staff, (Gordon, Holland and Lahelma, 2000) can be seen as a challenge to the official layers, which includes the teaching and learning, curriculum, pedagogy (ibid). Management of the need for social interaction amongst young people in school demands first acknowledgement and then a response, ideally informed by the students themselves. This work supports the argument that support of positive peer relationships in schools is a good way to promote the development of harmonious school communities where young people learn to support each other, aggression reduces, well being improves and perhaps academic standards rise.

\section{The conceptual context of the study}

It is generally accepted that friendships and positive social relationships are a good thing for young people, for their well being and for 'getting on in life'. For the young people in this study, secondary school represents the biggest collection of secondary school aged peers in their locality. In the context of schooling, the benefits of networks of peers for social well being are documented by many including Blatchford (1998), Ruddock and Flutter, (2004) and Fielding (2007). A recent comprehensive survey of young people's enjoyment of school by Gorard and See (2011) confirms the centrality of good social relations in schools in achieving this. The evidence for any benefits with regard to academic success is more contested and confused (see for example Epstein, 1983, Galton et al, 1999, Ganensen and Ehrich, 2009 and West et al 2010).

The complexity of young people's social worlds is acknowledged to be a difficult area to research (Thompson, 2001). The central importance of student friendships and relationships in schooling is recognised in the literature from various 
perspectives. Peer relationships and their complexities are seen through the lens of those interested in among others, motivation (eg Anderman et al 1994, Wentzel and Wigfield 2009), belonging (eg Goodenow and Grady, 1993) and social competence (eg Eliot, 2005).

In some places friendship is framed in terms of human capital theory, particularly social capital (e.g. Feinstein et al. 2008; Helve and Bynner, 2007, Lahelma 2002; Lupton et al. 2008). Helve and Bynner (2007) argue that it is during late childhood and adolescence that close interpersonal relationships such as parents, siblings and friends can operate as important sources of social capital. The work of Lupton et al. (2008) shows that school is an important place to make friends and that inschool networks of friends are more diverse than out-of-school networks and the extensive work of the 'Wider Benefits of Learning' (WBL) research group, reported by Feinstein et al. (2008), uses social capital theory in their identification of friendship as a key factor in school and wider social 'success'.

In the context of inclusion in schools, peers are seen as key players in both anchoring and preventing inclusive school practice. Through research work which listens to students, Allan (1999) argues that students act as gatekeepers allowing some of their peers 'in' but not others and Gunter and Thomson (2007) show that the complexities and intricacies of students' peer relationships have a significant part to play in determining whether students feel welcome in a school.

The importance of positive peer relationships is often discussed at times of school transition. Weller (2007) argues that in this context, it is 'particularly important that the implications of schooling as a social encounter are fully acknowledged in policy debates and initiatives' (p. 124). Generally, significant amounts of thought, time and 
energy are put in by schools and families to support friendship development particularly in transition phases (Galton and Morrison 2000).

It is clear from studies of lonely children that children who are not connected socially are vulnerable to social exclusion particularly in secondary schools (Gunter and Thomson, 2007, Qualter, 2003) which can have damaging affects on their well being (eg Kristensen, 1995) and academic performance at school (Qualter, 2003).

This study is focused on a secondary school-a phase of schooling where the school lives of the young people are complicated by the volatile nature of adolescence (Demetriou et al, 2000). Demetriou et al (2000) draw on the US literature review of motivation and schooling by Anderman et al (1994) which identifies this as a time of 'decreased investment (by students) in academic activities and increased investment in non-academic activities' (p288) - it's a time of increased importance of peer groups interaction.

Examining relationships within and between groups of peers is acknowledged as complex but it is argued here that further study of students' lived experiences of their relationships in schools is important as it holds the possibility of furthering understanding of how schools can become better places for young people to be (Gunter and Thomson, 2007).

\section{The case study}

This study focuses on the voices of a group of young people from an isolated rural community, called Morton. The study reported in the paper is part of a larger case study carried out as part of a doctoral research project. The researcher works as a teacher with young people in the study community who not attend school (as a result of exclusion, poor health etc). The planning and implementing of this research was informed by the 
British Education Research Association (BERA) 'Ethical Guidelines for Educational Research' (revised 2004). Pseudonyms have been used throughout, for places and individuals. In addition to the written consent from the students themselves, informed written consent was obtained from a parent or carer. Meetings with the students happened in school as this was a safe and straightforward place to meet although it is acknowledged that this decision did place the students and the teacher/researcher in familiar roles which has difficulties and complexities. No material incentives were offered, although it was sometimes necessary for the students to get permission to be out of lessons for interviews and they did seem to get personal satisfaction from the focus group and subsequent interviews.

This is not a work of 'voice' in the sense that those involved are 'subjects' actively involved in development of the project (Gunter and Thomson, 2007). It's a work of listening (Veck, 2007) attempting to minimise the indignity of speaking for others and the imposition of meaning on their words (Lather, 1991), whilst acknowledging that it is ultimately the researcher's interpretation that is recorded. The methodology was designed to 'turn up the volume' (Clough, 2002 p. 67) on quiet voices and so the research collected empirical evidence in an effort to avoid preconceived theories. The approach was informed by grounded theory interpreted from a social justice perspective (Charmaz and Mitchell, 2001).

\section{The geographical context}

Morton is an isolated village and many inhabitants experience poor housing and socioeconomic disadvantage. Poor access to services is a particular problem because of the geographical isolation. There is a small primary school (67 children on roll, 2011). The secondary school is in the town of Riversville nine miles away. Small cohorts of 
between 5 and 10 young people transfer to secondary school each year. The geographical context of this research, the secondary school, the rural isolation and deprivation are not unique being recorded across rural areas of the UK (Shucksmith, 2000) but rarely acknowledged in contemporary UK education policy.

The number of students from Morton with poor school attendance is significantly higher than the average for their school. When a student attends school for less than $80 \%$ of the required time, they are determined to have poor attendance. In this study, school attendance has been used as an indicator of the level of engagement with school by young people. A summary of attendance data from the secondary school in the 2 years prior to the start of this study is shown below and reveals the issues with poor attendance for the whole school and particularly for students from Morton.

Figure 1 Summary of Riversville College attendance data

\begin{tabular}{|c|c|c|}
\hline Academic year & $2005-6$ & $2006-7$ \\
\hline \multicolumn{3}{|l|}{ All students } \\
\hline$\%$ of all students at school with $<80 \%$ attendance & 12.49 & 11.90 \\
\hline \multicolumn{3}{|l|}{ Students from Morton } \\
\hline$\%$ of Morton students with $<80 \%$ attendance & 41.27 & 33.93 \\
\hline
\end{tabular}

There appear to be many barriers to regular school attendance for students from Morton. These include community inhabitants with very negative views of the secondary school, a 'culture' of disengagement in the community generally and the problem of disruptive and aggressive behaviour on the 'school bus' which is cited by parents, students and others from Morton as 'a massive problem'. So attending school regularly is quite an achievement and requires significant motivation. 


\section{The secondary school}

Riversville College is a community college serving an extensive rural area, with an almost entirely white, English speaking population. It is very large by UK standards, with a student population, (at July 2011), of around 1700. The school is managed as one whole school on one site, spread over 10 hectares. There were significant problems at the school with poor levels of student attendance, poor standards of student behaviour and high levels of formal (and other) student exclusions.

Tackling the poor student attendance and behaviour became school priorities during the period of the research. There was a new 'Behaviour for Learning' strategy, new rules about leaving the school site and there were new site security features.

Changes had also been made to the lesson and break time arrangements, with a 'split' lunch time so that the whole school was not on break together. The social and eating spaces at lunchtime were minimal with classrooms locked and students required to stay in the dining hall and another large building which the students called the 'cowshed', when inside. The arguments for these changes were presented as ways of controlling and managing student behaviour. It was a tense time in the school and a difficult place to work as a researcher. Communications with the head teacher were maintained throughout the study.

\section{Collecting the data}

Data for the case study were collected in a number of ways from a wide variety of documentary sources in the school and village. A wide range of people were interviewed including a Youth Worker, Parish Councillor, two parents of school aged children, Police Officer and the Community Safety Partnership Coordinator. People 
interviewed who were associated with the school included six students, eight members of staff, the Education Welfare Officer (EWO) and a school governor

As the data collection continued it became clear that the data derived from interviews with the young people from Morton were of primary importance and are considered the 'key' data. The other data played an important role in locating the research and situating the student interview data.

The primary data source was therefore a series of interviews carried out with a group of students. The interviews were transcribed directly and entirely without any ‘tidying' so can appear incomplete and disjointed. The content of interview transcripts were coded, key themes developed iteratively and anomalies and silences noted.

The 'pilot phase' of the study began at the Morton Youth Club where a 'youth empowerment programme' was being run by local Youth Workers for 13-18 year olds (There are about 18 students of this age group living in Morton). The researcher was invited to a session where young people talked about their experiences at school. Some young people agreed to talk in more detail. These initial self selected volunteers, Jo and Ivor (aged 16) and Marty (aged 17), were interviewed. Jo also opted to do an audio diary for a week which she recorded at home. The interviews were unstructured in order to challenge the 'truths' of official ways of seeing (May, 2001) and the privilege of speaking could give way to the act of hearing (Jones, 1998).

The initial volunteers recommended that some younger Morton students were also interviewed as they thought it would be useful to have their different perspective. They suggested Lenny (aged 13) and Ali (aged 15) who both agreed to be involved and Lenny brought his friend Mike (aged 13). Some students chose not to take part, including Robert and JR, whose silences are acknowledged. This 'snowball sampling', lead to a total of 6 students of being interviewed over a 2 year period. All the young 
people were regular school attendees which was important as the research set out to find out why these individuals went to school. A great deal was already known locally (through the work of the EWO and neighbourhood regeneration committee) about why others didn't. The small size of this group (which does represent a significant proportion of regular school attendees from this community aged 13-18) clearly limits the breadth of the information collected but offers the opportunity for sustained, deep engagement with the students.

Students came to interviews on their own, or in pairs. Each conversation generally began with the relating of a 'significant event' from that day or week in school. Generally the students needed few prompts to report how things were going for them in school. Care was taken not to 'lead' the conversation but some times interventions were made to direct the conversation towards further development of the student's ideas and views on school issues. Meetings with the young people happened in school, acknowledging that this decision placed the young people and the researcher in familiar roles with its inherent difficulties and complexities. It is also acknowledged that interviews are not 'neutral tools' (Atkinson and Silverman, 1997) and those involved have been involved in the collaboration and co-construction of the results (Fontana and Frey, 2005). No material incentives were offered, although the young people did get permission to be out of a lesson for the interview and did seem to enjoy the opportunity to talk. The students proved to be very willing and illuminating contributors to the project and their stories provide great insight into their lived experience of school.

\section{Emerging themes from the case study}


The data that has resulted from listening to these students reveals that they report their experience of school almost entirely as social activity. Their stories of both their 'official' school activities and their informal times are dominated by the social. Five key areas are presented in this following section: the central importance of the social relations between peers, the ordering of these relations, the exclusionary nature and the intensity of these relationships and relationships between these students and school staff.

\section{The central importance of social relations between peers}

The most compelling finding from the data is the central importance of social relations for these young people in school. When asked directly about good things that happen in school, these were invariably linked to social activities and 'friends' was frequently recorded as the most important thing about school. For example when asked about the good things about school, Ali says, 'My friends-some lessons -nothing else'. Marty has had to retake his GCSEs in year 12 and says it's grim because all his friends have gone and for Mike, the move to secondary school offers the opportunity to meet more of a similar age:

'Yes it was fine-you begin to like your new school better when there's more people.'

Jo and Lenny say school offers the chance to have friends from 'all over' as Morton is so small and offers so few opportunities: 
'Well, I like the people you meet-I've got a couple of friends

from Endean that came here-all over the place-I actually met one

of my mates that I knew down Selford, I went hey what are you

doing here and he went hey Lenny how are you doing?'

And for Lenny the promise of peers in makes the journey to school worthwhile:

'When you come down [from Morton] on the morning you are so relieved you are going to see your mates-yeah it's school but you can see who you like'

The promise of the social associated with school appears to play a significant role in the motivation for this group of students to go to school. The bus journey is not pleasant and it is cited by students as one of the reasons others don't go to school. So those students who do attend regularly have significant levels of motivation both intrinsic (from for example their desire 'to get a good education') and extrinsic (from for example encouragement by parents and the Morton Youth Workers). It appears from this data that the promise of associations with peers may well contribute to the motivation to attend school regularly.

\section{The ordering of social relations}

A dominant part of the 'social talk' about school is about the complex ordering and organisation of the relationships between students in school.

Below is an example of how ordering of social relations is evident from a conversation with Lenny and Mike about which students do well in schools. 
Cath Who do you think usually gets a good deal in school?

Mike $\quad$ The most popular ...

Cath The most popular kids, they get a good deal right?

Mike $\quad$ Yes they walk around at lunch time with their big group of mates they just ...And get on....

Cath Right so if you can walk around at lunch time with a big group of mates and everybody knows you, it must mean you're successful?

Lenny I had a booster and so does Mike because I everyone in Year 10 knows my older brother and that gives me like an extra group of people who have lots of younger brothers and sisters who knew me and because me and Mike stay close together and we started going around and eventually me and Mike we know basically everyone in our Year now don't we?

Lenny If you are popular you get good deals with the kids and if you're perfect you get good deals with teacher.

Lenny and Mike are both in year 8 so relatively new to secondary school. They seem to have adjusted well to the scale of the new school. Both talk about the benefits of being 
associated with big groups of people-it gives a link through 'popularity' to 'power'. Being seen to know lots of people suggests you are popular and being 'popular' is good. The Morton students talk generally about popularity, linking it to 'power' almost using the two words interchangeably. Being 'popular' is clearly seen as an advantage with both peers and teachers. They go on to say that knowing lots of people also offers 'protection' as being 'high up' means you won't be bullied.

In the section below Lenny mentions specifically the benefits he sees of coming from somewhere big (unlike Morton):

$$
\begin{aligned}
& \text { if you're from somewhere big and you know a } \\
& \text { lot of people then you're like in your locality in } \\
& \text { college and you're like happy there already then } \\
& \text { you like say to everyone I know Year } 10 \text { I know } \\
& 11 \text { and they automatically think Oh he knows a } \\
& \text { lot of people I'll hang out with him and } \\
& \text { eventually it just piles on. }
\end{aligned}
$$

Coming from a tiny community like Morton and knowing few people would seem to give these students an instant disadvantage in the 'popularity/power' game and leaves them vulnerable. The poor attendance at school of their peers may be linked to this vulnerability.

\section{Exclusionary nature of the relationships - 'Being out'}

Some of these relationships are seen as important and positive by the students but others cause problems. The students provide insights into the exclusionary nature of these social relations. There are specific examples where students discuss their concerns for other students from Morton who come to school but are excluded from the social 
mainstream. Lenny and Mike discuss Robert who did not want to take part in the study. He is in the same year group and since transferring from primary school. Lenny said:

'he's a kind guy, he wouldn't hurt a fly he really would not and he sort of shut down when he got here, he went into a corner with other people and I say come on, come up here come with me but he said no, he wouldn't come with me'.

And Mike sees the difficulties for Robert 'being out' of a group:

'like last year, all the people that was like popular, they was all in a big group of friends sort of thing and Robert got in with like the kids who didn't talk much and he dropped out sort of thing'.

Robert now works solely with the Learning Support team and his school attendance is recorded as 'patchy'.

Jo and Ivor talk about JR who transferred with them from primary school and is again not happy at the secondary school:

Jo it [bullying] happens to JR really badly

Ivor but JR puts himself in it sometimes. JR is cool, he's alright he's a good guy, but he tries to like join in 
conversations and he acts like he's all cool and someone else just comes along and...

Jo that's because he's being himself probably and then if people don't like him

Ivor no no, he's not being himself. He even says in Maths he just wants to join in and he just butts into other people's conversations

Jo do you know why that is? Because nobody wants to talk to him because of his eyes

Ivor yes, we do, everybody in our class...

Jo but think about the rest of the school? That's like 200 people, the only people he has to talk to... [Is us lot]

Lenny has tried to get Robert to 'fit in'- to be like others and to do what others do and Jo has clearly made an effort to prevent JR's exclusion from social situations. The students express real concern for the excluded students and acknowledge that disconnection is a problem. Not being part of the social mêlée has lead to problems for JR and Robert and both have poor attendance records. The data from this small group of students concurs with that of other studies (eg Qualter, 2003) which argue that students are vulnerable when they are socially isolated in school.

\section{The intensity of the relationships}

The descriptions the students give suggest that their peer relationships are very intense and dominate their daily school lives. There is evidence in the data that these intense peer relations challenge boundaries in the school. The intensity of the students' 
social relations appears to spill over into lessons and other formal and informal spaces in school and emerge as problem behaviour, fights etc. All the students comment on how disruptive behaviour and fighting goes on all the time and that the teachers don't have any control. Lenny talks about trying to 'mediate' between groups of feuding students in his particularly problematic tutor group and the disruptive behaviour in classes frustrates Jo and Ivor who are in year 11, trying to focus on their GCSE exam subjects. There are unsurprisingly many inconsistencies in the students' views. Here, in an extract from Jo's audio diary, she shows how her own social life spills into the classroom and then brings her into conflict with staff:

'well, I've started going out with this guy called B, well I didn't even ask him to come to my lesson, but he came and sat outside the door of my art room, and then I went bright red so I just walked off, I didn't really want to talk to him. So then Mr C went over and talked to him and apparently he was being really rude to him. I don't know if he was or not, because I wasn't anything to do with it. But then Sir picked on me and was just like if you don't tell me his name, raa, raa, raa - sorry I'm not going to do that, why are you only asking me, why can't you ask anyone else in the class? And he was just having a right go at me; he was like I'm not going to enter you for your art GCSE. And I said, what, because somebody came to the door? He was like, yes, plus he was being rude to me. And I said, well, that's not my problem, that's between you and him. Rrrrr.' 
This incident is just one of many for Jo who is frequently in trouble and in dispute with teachers, invariably as a result of her associations with friends (and enemies) spilling into spaces in school where they cause a disturbance and bring her into confrontation with teachers. A similar thing happens to Ali, for example:

'say if you are with a group of people and lets say they want to go a certain area of the school that's out of bounds and you're not doing what they are doing but you are just there, you get labelled as if you were doing what they were doing but you are just there, you get labelled as if you were doing what they were doing - if you know what I mean and you get in as much trouble for being there rather than for actually doing it. So that's what really irritates me because if you're just there and there's nowhere else and you want to be with your friends, you get in trouble'.

Ali talks often of how she gets into trouble because she just wants to be with her friends. This excerpt also draws attention to the limited provision of social spaces in the school-Ali notes here that there is 'nowhere' else to go.

\section{Relationships between students and school staff}

The student interview data reveals generally poor relationships between these students and teachers. In this next excerpt, Lenny and Mike are talking in response to a question about adults that they saw as helpful: 
Lenny yeah he's [Mr North, a Learning Mentor] OK to talk to I talk to him sometimes

Cath so who else would you talk to if you know - needed to talk about something?

Lenny you mean a teacher?

Cath anybody in school

Lenny for me I'd go to talk to Steve [a friend] or something if I needed someone bigger I'd go to my brother or one of his mates

Cath so you'd talk to friends first?

Lenny yeah - teachers would be the last option...

Cath that's interesting - not even someone like Mr North?

Lenny he'll make you feel better but he won't stop the problem what are they going to do, put them on report? - that's not going to stop them

Cath what about you, Mike? - if you had a problem in school or needed some help with something- what sort of people would you talk to?

Mike my friends

Cath not teachers, not classroom assistants or helpers?

Mike no

Cath really, why not?

Mike cos friends understand and could sort the problem and do stuff about it

Cath friends do? 


\section{Lenny/Mike yeah}

These students saw teachers as the last place to go for help. For these students, peers were seen as much more important sources of help and support than teachers. The data suggests that in this school, the student body with its own rules, systems and structures has become more independent and separated from the formal layers in the school leading to problematic interpersonal relationships generally between students and between teachers and students.

\section{Interviews with adults at school}

This paper has focussed on the voices of some young people from Morton. In order to contextualise these student responses, a sample of adults in the school was interviewed including the principal, an assistant principal, the SENCO, a form teacher, a lunchtime assistant, a learning mentor and student services officer. These adults expressed a range of perspectives on their roles in school and how this links with students. There were significant differences between the responses from teachers and support staff. All the teachers focused on the bureaucratic processes involved in their roles and their concerns about attendance and poor behaviour. Their discourse is dominated by the language of the 'standards agenda. For example here is the assistant principal talking about inclusion and exclusion, two of his responsibilities:

'There is a decrease [in exclusion] generally - in school and between local schools. The LEA is leading the re-siting of "troublesome students' - called 'fresh start'. In isolated communities this is very

difficult. There is reluctance for schools to take on extreme problems 
Admin and bureaucracy are also getting in the way of teaching - a significant amount of time is taken away from students leads to a decrease in care. There's a government initiative every week leading to a new load for teachers.'

There were, however, 3 members of school staff who did speak at length about school as a social place for students. They were all support staff; a learning mentor, student services officer and lunchtime supervisor. All three expressed concern about the general lack of understanding of the importance of this within the school. The learning mentor spoke of the importance of the 'gossip and slagging off' but was concerned for those 'who don't, won't or can't engage in all of this' as they get isolated and, disconnected'. The student's services manager spoke of the importance of having someone the students could rely on to sort out 'little niggles before they got into big problems'. The lunchtime supervisor was particularly concerned by the physical challenges of the school including lack of provision for social space at lunchtime.

It is clear from the interviews with students and staff that the school is a 'highly striated and sedentary' (Patton 2000) place. The social relations of the students seem to operate in a separate layer which is closely controlled and regulated with its own rules (Youdell, 2006). The boundaries between the students and the school staff seemed well entrenched, as Lenny says, teachers 'would be the last option' if you needed someone to talk to in school.

\section{What we can learn from this data}

In this study, the students involved came from a community where there were challenging socio-economic circumstances and generally negative attitudes to authority 
including schools. Those that made it to school each day, overcoming significant barriers, were clearly motivated to attend school. The data shows that included in their motivations to attend school was the importance they placed on school as a place to 'see mates'. It is not surprising that the findings of this study confirm that 'the social' is central for this group of students which is significant for them but also has implications for their peers who won't or can't manage the intensity of the social mêlée in this school, for whatever reason. Acknowledgement of the importance of these interactions for the students by the school staff and managers may be a key to developing a more inclusive, enjoyable and successful school environment.

This group of students are focused on the social elements of the informal layers of the school and appear to have generally poor relationships with teachers. The informal layers school seem to be spilling into the official layers leading to disruption of the teaching and learning, poor behaviour and high levels of exclusion in all forms. In Lahelma's (2002) studies of urban secondary schools, she showed that the 'invasions of the informal on the official agenda form a recurrent source of conflict between teachers and (some) students' (p. 379). She argues that 'teachers are bound to fail in their efforts to keep the informal (social) outside of lessons' (p. 379) and that education practitioners and researchers should look for ways to see young people's need to interact with each other as a resource rather an as a disturbance. The social elements of schooling need to be acknowledged and accommodated pedagogically and spatially in schools (Gordon, Holland, and Lahelma, 2000).

There seem to be particular issues with poor provision for social spaces at Riversville. The students report they have 'nowhere to go' and the buildings that are available are not well suited for social activity. The discourse of the teachers and managers is dominated by the language of the 'standards agenda' and concerns about 
attendance and behaviour. Acknowledgement of the significance of the school as a social place is not recorded in any data collected from school managers.

Fielding (2007) argues that the focus of contemporary education policy on 'performativity' with its framework of targets and standards is fundamentally exclusionary because it does not recognise the humanity within a school. He argues that in order to expose and oppose this hegemony there is a need to reclaim the human in schools. Here schools are designed specifically for human engagement, 'their organisational architecture is informed by manifest interpersonal intentions' (Fielding, 2007 p. 403) with spaces where students can connect with each other and their teachers through shared engagement. These might be collective pedagogical spaces: students working together with teachers on a series of lesson plans or meeting to discuss the shared development of curriculum or policy across the school. These sorts of spaces in which the development of teaching and learning is shared, would offer staff and students at Riversville opportunities to develop relationships within the formal layers of the school.

Fielding also argues for physical spaces in schools, designed specifically for human engagement (Fielding, 2007). In the context of Riversville College this would suggest consideration is given to the way in which physical space in and around the college is designed and developed, to ensure they are good places for individual and group human encounter. For example one of the dining halls which the students call 'the cow shed' has a high metal roof and no ceiling which makes it a noisy, unpleasant social space. The development of spaces where the acoustics allow for good listening would improve break and lunchtimes considerably. Inside and outside spaces where students feel safe in break and lunchtimes to meet friends, deal with disagreements etc would also be a useful addition at the College. Involving students in the design of 
school buildings and discussions on the use of spaces such as this would offer opportunities for shared engagement.

\section{Conclusion}

It has been have argued in this paper that the social needs of these secondary students should be acknowledged and embraced in this school's drive to become a place where young people feel safe and can be successful. This research concurs with other studies that indicate students benefit from the social element of schooling in many ways. For young people from small rural communities, secondary school clearly provides a big collection of peers and the promise of 'seeing mates' may be a significant factor in the motivation of these students to attend school in the first place. There also appear to be benefits for these students through their social capital-they 'have friends from all over' at school, thus widening their social networks and range of contacts.

However the intensity of the relationships amongst the students is concurrent with observations made in the school which suggest there is separation of the layers of the school inhabited by the students from the teachers and other staff. These observations are also contingent with the observations of poor behaviour, poor attendance and high levels of exclusions at the school. It is suggested here that there may well be links between the lack of provision for and acknowledgement of the significance of the student's social needs within the formal layers of the school and the general sense of disruption, disconnection and unhappiness. It would seem that developing spaces physically and pedagogically for the social needs of young people in secondary schools continues to be central to building school communities that are harmonious, successful and where young people want to be. 


\section{References}

Allan, J. (1999) Actively seeking inclusion. London: Falmer Press.

Anderman, E., Maehr, M. and Martin, L. (1994) Motivation and schooling in the middle grades. Review of Educational Research, 64, 287-309.

Atkinson, P. and Silverman, D. (1997) Kundera's immortality: the interview society and the invention of the self. Qualitative Inquiry, 3, 304-325.

Blatchford, P. (1998) Social life in school: pupil's experience of breaktime and recess from 7-16 years. London: Falmer Press.

Charmaz, K. and Mitchell, R. (2001) Grounded theory in ethnography, in: P. Atkinson, A. Coffey, S. Delamont, J. Lofland, and L. Lofland. (Eds.) Handbook of ethnography. London: Sage.

Clough, P. (2002) Narratives and fictions in educational research. Buckingham: Open University Press.

Demetriou, H., Goalen, P. and Ruddock, J. (2000) Academic Performance, transfer, transition and friendship: listening to the student voice. International Journal of educational Research, 3 (33), 425-441.

Eliot, A. (2005) Handbook of competence and motivation. New York: Guildford Press. Epstein, J. (1983) The influence of friends on achievement and affective outcomes. In JL. Epstein and N. Karweit (Eds.) Friends in school: patterns of selection and influence in secondary schools. London: Academic Press

Feinstein, L., Budge, D., Vorhaus, J. and Duckworth, K. (2008) The social and personal benefits of learning: a summary of key findings. Centre for Research on the Wider Benefits of Learning. London: Institute of Education. 
Fielding, M. (2007) The human cost and intellectual poverty of high performance schooling: radical philosophy, John Macmurray and the remaking of person-centred education. Journal of Educational Policy, 22(4), 389-409.

Fontana, A. and Frey, J. (2005) The interview, in: N. Denzin and Y. Lincoln (Ed.s) The Sage handbook of qualitative research (3rd edition). Thousand Oaks, California: Sage. Galton, M., Gray, J. and Ruddock, J. (1999) The impact of school transitions and transfers on pupil progress and attainment. A DfEE report. Norwich: HMSO. Galton, M. and Morrison, I. (2000) Concluding comments. Transfer and transition. The next steps. International Journal of educational Research, 3(33), 425-441.

Ganensen, K. and Ehrich, L. (2009) Transition into High School: a phenomenological study. Educational Philosophy and Theor,. 41 (1), 60.

Goodenow, C. and Grady, K. (1993) The relationship of school belonging and friends values to academic motivation among urban adolescent students. Journal of Experimental Education,. 62(1), 60-71.

Gordon, T., Holland, J. and Lahelma, E. (2000) Making spaces: citizenship and difference in schools. Basingstoke: Macmillan Press.

Gorard, S. and See, H. B. (2011) How can we enhance enjoyment of secondary school? The student view. British Educational Research Journal., 37 (4), 671-690.

Gunter, H. and Thomson, P. (2007) Learning about student voice, Support for Learning, 22(4), 181-188.

Helve, H. and Bynner, J. (Eds.) (2007) Youth and social capital. London: The Tufnell Press.

Jones, A. (1998) Pedagogical desires at the border: absolution and difference in the university classroom. Winds of change: women and the culture of the universities. International conference. July 1998 (Sydney, Australia). 
Kristensen, K (1995) The lived experience of childhood loneliness: a phenomenological study. Issues in Comprehensive Nursing, 18,125-137.

Kvalsund, R. \& Hargreaves, L. (2009) Reviews of Research in Rural Schools and Their Communities: analytical perspectives and a new agenda. International Journal of Educational Research, 48(2), 140-149.

Lahelma, E. (2002) School is for meeting friends: secondary school as lived and remembered. British Journal of Sociology of Education, 23(3), 367-381.

Lather, P. (1991) Getting smart: feminist research and pedagogy within the postmodern. New York: Routledge.

Lupton, R., Salter, E., Heath, N., Stevens, P. and Mujtaba, T. (2008) Social mixing, community cohesion and social isolation: an exploratory analysis of friendship networks in two London secondary schools, in: Centre for Research on the Wider Benefits of Learning (Ed) Young people, their social networks and school support: exploratory analysis of friendships, well being and multi-agency working in two inner London secondary schools. Discussion paper. London: Institute of Education. May, T. (2001) Social research; issues, methods and processes. Maidenhead: Open University Press.

Patton, P. (2000) Deleuze and the political. London: Routledge.

Qualter, P (2003) Loneliness in children and adolescents: what do schools and teachers need to know and how can they help? Pastoral Care in Education, 21(2), 10-18.

Rudduck, J. and Flutter, J. (2004) How to Improve your School: Giving Pupils a Voice. London: Continuum Press.

Shucksmith, M. (2000) Exclusive countryside? Social inclusion and regeneration in rural areas. York: Joseph Rowntree Foundation. 
Thompson, T. (2001) Best friends, worst enemies: understanding the social lives of children. New York: Ballantine.

Veck, W. (2007) Listening to include. International Journal of Inclusive Education. 115. http://dx.doi.org/10.1080/13603110701322779

Weller, S. (2007) Managing the move to secondary school: the significance of childrens' social capital, in: H. Helve and J. Bynner (Ed.s) Youth and social capital. London: The Tufnell Press.

Wentzel, K. and Wigfield, A. (Eds) 2009. Handbook of motivation at school. New York: Routledge

West, P., Sweeting, H., and Young, R. (2010) Transition matters: pupil's experience of the primary-secondary school transition in the west of Scotland and consequences for well-being and attainment. Research Papers in Education, 25(1), 21-50.

Youdell, D. (2006) Impossible bodies. Impossible selves. Exclusions and student subjectivities. Dordrecht: Springer. 